\title{
Attenuation of glycation and biochemical aberrations in fructose-loaded rats by polyphenol-rich ethyl acetate fraction of Parkia biglobosa (jacq.) Benth. (Mimosaceae) leaves
}

\author{
Christian Chiazor Chibuogwu ${ }^{1,2}$, Rita Onyekachukwu Asomadu ${ }^{1 *}$, Innocent Uzochukwu Okagu ${ }^{1 *}$ (D), \\ Chinelo C Nkwocha ${ }^{2}$ and Ben Chibuzo Amadi ${ }^{2}$
}

\begin{abstract}
Background: Different parts of the Parkia biglobosa plant are employed in traditional medicine in different African communities. However, information ratifying its use and biochemical influence on health is still scanty in literature. Thus, the present study assessed the influence of the ethyl acetate fraction of Parkia biglobosa leaves (EAFPB) on some biochemical parameters of sub-chronic fructose-loaded rats.

Methodology: Twenty-five Wistar rats were randomized into five groups $(n=5)$. The normal control group was maintained on normal diet only while the high fructose solution (HFS) control (placebo), reference and treatment groups received high fructose solution ( $3 \mathrm{~g} / \mathrm{kg} / \mathrm{d}$ b.w of fructose) for 30 days before treatment. Based on pilot study, two doses (100 and $200 \mathrm{mg} / \mathrm{kg} / \mathrm{d}$ b.w) of EAFPB were selected and were administered to two groups of test animals while the reference group received $300 \mathrm{mg} / \mathrm{kg} / \mathrm{d}$ b.w. of metformin for 14 days. Thereafter, blood was collected from fasted animals for biochemical analyses for the examination of level of glycated hemoglobin $(\mathrm{HbA1c})$, liver status (alanine and aspartate aminotransferases (ALT and AST) and alkaline phosphatase (ALP) activities, and bilirubin level), lipid profile (total cholesterol, triglyceride, and low- and high-density lipoproteins levels) and lipid peroxidation (malondialdehyde - MDA level).

Results: EAFPB was shown to have a good DPPH radical scavenging activity $\left(E_{50}=0.395 \mathrm{mg} / \mathrm{ml}\right)$. Chromatographic analysis of EAFPB revealed 28 known flavonoids (mainly kaempferol $(21.31 \mathrm{mg} / 100 \mathrm{~g}$ ), quercetin $(12.84 \mathrm{mg} / 100 \mathrm{~g})$, and luteolin $(6.75 \mathrm{mg} / 100 \mathrm{~g})$ ), four hydrocinnamic acids derivatives (mainly P-coumaric acid $(6.73 \mathrm{mg} / 100 \mathrm{~g})$ ), and 11 phenolic acids derivatives (mainly chlorogenic acid (48.18 mg/100 g) and protocatechuic acid $(21.58 \mathrm{mg} / 100 \mathrm{~g})$ ). Relative to normal control, it was observed that fructose overload significantly increased serum activities of ALP, ALT, and AST, and levels of MDA, total cholesterol, low density lipoprotein and triglyceride in placebo. However, EAFPB significantly tapered the elevated serum activities of ALP, ALT, and AST. In addition, relative to placebo, the increased levels of $\mathrm{HbA1c}, \mathrm{MDA}$, and lipid health markers were also rebated by EAFPB.

(Continued on next page)
\end{abstract}

\footnotetext{
*Correspondence: rita.asomadu@unn.edu.ng; innocent.okagu@unn.edu.ng ${ }^{1}$ Department of Biochemistry, Medical Biochemistry, Toxicology and Drug Discovery Unit, University of Nigeria, Enugu State, Nsukka, Nigeria Full list of author information is available at the end of the article
}

\section{Springer Open}

(c) The Author(s). 2021, corrected publication 2021. Open Access This article is licensed under a Creative Commons Attribution 4.0 International License, which permits use, sharing, adaptation, distribution and reproduction in any medium or format, as long as you give appropriate credit to the original author(s) and the source, provide a link to the Creative Commons licence, and indicate if changes were made. The images or other third party material in this article are included in the article's Creative Commons licence, unless indicated otherwise in a credit line to the material. If material is not included in the article's Creative Commons licence and your intended use is not permitted by statutory regulation or exceeds the permitted use, you will need to obtain permission directly from the copyright holder. To view a copy of this licence, visit http://creativecommons.org/ licenses/by/4.0\%. 
(Continued from previous page)

Conclusions: Ethyl acetate fraction of Parkia biglobosa leaves attenuates biochemical aberrations in fructose-loaded rats, an effect attributable to the rich store of polyphenolic compounds in the fraction.

Keywords: Parkia biglobosa, Fructose, Polyhenolic compounds, Dyslipidemia, Glycated hemoglobin, Antioxidant

\section{Introduction}

Nutrition is largely recognized to play a major role in the health and wellbeing of individuals. Thus, intake of high calorie foods, with increased sedentary lifestyles, is widely recognized as the major contributor to the epidemic of many metabolic diseases. Several reports have linked high calorie foods (in the form of sugars) to the alarming increases in cases such as non-alcoholic fatty liver disease and the metabolic syndrome (a group of interconnecting factors which enhance the risk of cardiovascular diseases and type-2 diabetes) [1,2]. Sugar in the form of sucrose (glucose and fructose in equal amounts) or high-fructose corn syrup (consisting up to $55-60 \%$ of fructose in its free form) are incorporated into many diets worldwide, including soft drinks and many pre-packaged foods such as breakfast cereals and baked goods [3]. Studies have reported the adverse effects of excess circulating sugars on both intra- and extracellular macromolecules $[4,5]$. Although there are no specific data indicating daily thresholds of calories from sugars which could negatively affect human health, several experimental results indicate negative health effects of high sugar intake. Prolonged ingestion of high fructose (from foods and drinks) is associated with negative metabolic effects including increased hepatic lipogenesis with a concomitant hepatic and extrahepatic fat deposition. It is also implicated in incidences of hypertriglyceridemia, and insulin resistance, increased oxidative stress, and increased plasma and tissue accumulation of intermediate and advanced glycation products [6].

A number of phytochemicals from natural sources are associated with positive health outcomes in many disease conditions with many of them applied in modern medicine [7-9]. Parkia biglobosa (Jacq.), popularly known as African locust bean tree belongs to Leguminosae family and is a native to West Africa. It is known as Dorowa (Hausa), Ogiri (Igbo) and Iru (Yoruba) in some Nigerian languages. The fermented seeds are commonly used as seasoning for soups in many parts of Nigerian. Previous studies have reported some biological activities of different parts of this plant and its anti-hyperglycemic effects have been documented [10, 11]. Ibrahim et al. [12] also reported potent antioxidant activity of the different parts of $P$. biglobosa in vitro. There are, however, no reports on its biochemical effects in calorie-induced aberrations. Hence the assessment of the effect of ethyl acetate fraction of P. biglobosa leaves on some biochemical markers of fructose-loaded Wistar albino rats.

\section{Materials and methods}

\section{Chemicals and Instruments}

Instruments used were weighing balance (Vickas Ltd, England), centrifuge (Vickas Ltd, England) and spectrophotometer (E312 Model) (Jenway, UK) while reagents for the biochemical experiments were products of Randox (USA). Other chemicals were methanol and nhexane (Loba Chemie, India), ethyl acetate and 2,2diphenyl-1-picrylhydrazyl (DPPH) (Sigma Aldrich, Germany), Silica gel (JHD, China), fructose (Qualikems, India) and STANDARD A1cCare Test Kit (SD BIOSENSOR, Korea). All chemicals were of analytical grade.

\section{Experimental animals}

The animals used in this study were inbred healthy male adult Wistar rats (75-150 g) used for the intervention studies. They were maintained on standard animal feed (Grand Cereals Limited, Nigeria) and water ad libitum.

\section{Plant sample}

Fresh leaves of $P$. biglobosa were collected from a farm in Mkpor, Nsukka LGA of Enugu State, Nigeria and authenticated by John Nwachukwu, a taxonomist at the University of Nigeria, Nsukka and voucher specimen was submitted at the herbarium of Department of Plant Science and Biotechnology (UNH/147). Air-dried and powdered sample was defatted using $n$-hexane and then extracted by maceration in methanol for $48 \mathrm{~h}$. The filtrate was dried at $40^{\circ} \mathrm{C}$ to obtain the crude methanol extract which was fractionated by vacuum-liquid chromatography as described by Nwankwo [13] using silica gel as stationary phase. The solvent fractions were collected and evaporated to dryness and stored at $2-8^{\circ} \mathrm{C}$. Pilot study showed that ethyl acetate fraction (EAFPB) was more active and was then chosen for intervention study.

\section{Preliminary Phytochemical analyses}

The method of Harborne [14] and Trease and Evans [15] were adopted for the preliminary phytochemical analyses of the fraction.

\section{Preparation of the Sample for Gas Chromatography analysis Hydroxycinnamic acids}

following the description of Ortan et al. [16], the hydroxicinnamic constituents of the sample were extracted 
with methanol and the resulting extract filtered and concentrated to $1 \mathrm{ml}$ for analysis.

\section{Flavonoids}

As described by Millogo-Kone et al. [17], $0.5 \mathrm{~g}$ of the sample was boiled in deionized water for $10 \mathrm{~min}$ followed by the addition of $100 \mathrm{ml}$ boiling methanol: water $(70: 30 \mathrm{v} / \mathrm{v})$ to obtain the flavonoid extract. The homogenate was left for about $4 \mathrm{~h}$ before filtration and derivatization for volatility in GC analysis. The mixture was then concentrated to $2 \mathrm{ml}$ ready for analysis.

\section{Phenolic Acids}

$50 \mathrm{mg}$ of the sample was extracted with $5 \mathrm{ml} 1 \mathrm{M} \mathrm{NaOH}$ for $16 \mathrm{~h}$ at ambient temperature as described by Kelley et al. [18] and Provan et al. [19]. This was followed by centrifugation (5000 $x \mathrm{~g}$ ), rinsing, and further centrifugation. The supernatants were pooled and then heated for $2 \mathrm{~h}$ at $90^{\circ} \mathrm{C}$ to liberate the conjugated phenolic acids [20]. After cooling, the extract was titrated with $4 \mathrm{M}$ $\mathrm{HCl}$ to $\mathrm{pH}<2.0$, diluted to $10 \mathrm{ml}$ with deionized water, followed by centrifugation and further purifying of the resultant supernatant.

\section{Purification of phenolic acids and GC conditions for sample analysis}

A fraction $(15 \mathrm{ml})$ of the supernatant obtained above was passed through a Visiprep-attached PPL solid-phase extraction tube (3-mL size with $200 \mathrm{mg}$ packing) (conditioned with $2 \mathrm{~mL}$ each of ethyl acetate and water $(\mathrm{pH}<$ 2.0)) at $5-\mathrm{mL} \mathrm{min}^{-1}$. Then the resin was completely dried by vacuum treatment $(-60 \mathrm{kPa})$ and the phenolic acids eluted into gas chromatography Autosampler vials with ethyl acetate $(1 \mathrm{~mL})$. Chromatographic analysis was carried out on an HP 6890 (Hewlett Packard, Wilmington, DE, USA) GC apparatus, fitted with a flame ionization detector (FID), and powered with HP Chemstation Rev. A 09.01 [1206] software to quantify and identify compounds. The column was a capillary HP INNOWax Column $(30 \mathrm{~m} \times 0.25 \mathrm{~mm} \times 0.25 \mu \mathrm{m}$ film thickness). The inlet and detector temperatures were $250^{\circ} \mathrm{C}$ and $320^{\circ} \mathrm{C}$ respectively, split injection with a split ratio of 20:1 was used and the carrier gas was Nitrogen. For flavonoids detection, the hydrogen and compressed air pressures were $22 \mathrm{psi}$ and 35 psi respectively. The oven was programmed to $50^{\circ} \mathrm{C}$ initial temperature, $8^{\circ} \mathrm{C} /$ min first ramping for $20 \mathrm{~min}$, and maintained for $4 \mathrm{~min}$, followed by a second ramping at $12 \mathrm{C} / \mathrm{min}$ for $4 \mathrm{~min}$, maintained for $4 \mathrm{~min}$. similarly, for the detection of hydroxycinnamic acids derivatives, the hydrogen and compressed air pressures were 25 psi and 38 psi respectively. The oven was programmed to $50^{\circ} \mathrm{C}$ initial temperature, $8^{\circ} \mathrm{C} / \mathrm{min}$ first ramping for $20 \mathrm{~min}$, and maintained for $4 \mathrm{~min}$, followed by a second ramping at
$10 \mathrm{C} / \mathrm{min}$ for $4 \mathrm{~min}$, maintained for $3 \mathrm{~min}$. in addition, for the detection of phenolic acids derivatives, hydrogen and compressed air pressures were 28 psi and 32 psi respectively. The initial oven temperature was $60^{\circ} \mathrm{C}$ for $5 \mathrm{~min}$, with first and second ramping maintained at $15^{\circ} \mathrm{C} / \mathrm{min}$ for $1 \mathrm{~min}$ and $10 \mathrm{C} / \mathrm{min}$ for $4 \mathrm{~min}$, respectively.

\section{2,2-diphenyl-1-picrylhydrazyl (DPPH) radical scavenging activity of the ethyl acetate fraction}

The DPPH radical scavenging activity of the ethyl acetate fraction was determined as previously described [21], with slight modification. Briefly, a solution of $0.135 \mathrm{mM}$ DPPH in methanol was prepared and $1 \mathrm{ml}$ of this solution was mixed with $1 \mathrm{ml}$ of the fraction and standard separately (BHT) $(0.025-0.5 \mathrm{mg} / \mathrm{ml}$ concentrations) prepared in methanol. The reaction mixture was kept for $30 \mathrm{~min}$ in the dark and at room temperature after thorough mixing. The absorbance of the resulting mixture, read at $517 \mathrm{~nm}$ with a spectrophotometer, was used to calculate the radical-scavenging efficacy of the sample as follows:

Radical scavenging efficacy $=\frac{\text { Abs control-Abs sample }}{\text { Abs control }} \times 100$

\section{Intervention study design}

The study protocols were approved by Faculty of Biological Sciences Committee on Research and Bio-Ethics (UNN/FBS/EC/1056). A total of five groups of experimental rats $(n=5)$ were used: all the animals, except those in group 1 (normal control), were administered high fructose solution (HFS) (3 g/ $\mathrm{kg}$ body weight fructose dissolved in distilled water) for 30 days before drug administration. Group 2 served as HFS control group (without treatment), the reference group (group 3) was treated with $300 \mathrm{mg} / \mathrm{kg} / \mathrm{d}$ b.w., p.o of Metformin, while the treatment groups (groups 4 and 5) were administered 100 and $200 \mathrm{mg} / \mathrm{kg} / \mathrm{d}$ b.w., p.o EAFPB, respectively for two weeks. After the intervention period, the 12-hr fasted experimental rats were exsanguinated via cardiac puncture under mild anesthesia into both anticoagulantcontaining and clot activator-containing containers. The containers were spun at $4000 \mathrm{~g}$ for $10 \mathrm{~min}$ and plasma derived from the anticoagulant-containing container were used for glycated hemoglobin (HbA1c) test while sera from clot activator-containing containers were used for the liver function, lipid profile, lipid peroxidation and antioxidant tests.

\section{Determination of $\mathrm{HbA1c}$ levels of experimental animals}

The HbA1c levels of the animals were determined by the immunoassay and reflectometry method using the STANDARD $^{\mathrm{TM}}$ A1cCare test kit. The principle is based 
on the immunoassay and reflectometry. The kit uses an anti-HbA1c (\%) antibody which is specific for the first few amino acid residues of the glycated $\mathrm{N}$-terminus of the beta chain of hemoglobin A0. The kit contains the test panel (nitrocellulose membrane), latex tablet (blue dyed latex micro-particles conjugated to specific antibodies) and buffer solution (hemolysis reagent). When whole blood is added to the buffer solution and is mixed with the latex tablet, the erythrocytes are instantly lysed to release the hemoglobin (HbA1c in this case). When sample mixture is loaded onto the sample port of the test panel, the mixture fluid migrates along the membrane of test panel by capillary action and the HbA1c gets immobilized onto the anti-HbA1c antibody-coated line. At the same time, latex conjugate binds to HbA1c. A photometric sensor measures the LED light reflected and then $\mathrm{HbA} 1 \mathrm{c}$ is calculated.

\section{Determination of biochemical indices}

Total bilirubin concentration was determined by colorimetric method described by Jendrassik and Grof [22]. Alanine aminotransferase (ALT) and aspartate aminotransferase (AST) activities were assayed following the protocol of Reitman and Frankel [23] while alkaline phosphatase (ALP) activity was assayed by the method of Englehardt [24]. Lipid peroxidation was determined by measuring malondialdehyde concentration following Wallin et al. [25] method. In addition, reduced glutathione concentration was determined using the method of Habig et al. [26]. Furthermore, serum total cholesterol, high density lipoprotein (HDL) and triglyceride (TRIG) concentrations concentration was determined using the methods of Allain et al. [27] and Albers et al. [28], respectively as contained in QCA commercial kits. Similarly, serum low density lipoprotein (LDL) was determined by modified method of Friedwald et al. [29], as the difference between total cholesterol and the cholesterol content of the supernatant after precipitation of the LDL fraction by polyvinyl sulphate in the presence of polyethylene glycol monomethyl ether.

\section{Results}

\section{Phytochemical constituents of EAFPB}

The analyses of some phytoconstituents of the ethyl acetate fraction of P. biglobosa leaves (EAFPB) (Table 1) showed relatively high concentration of phenolics and tannins, moderate concentrations of flavonoids and terpenoids, while alkaloids concentration was very low compared to the other phytochemicals tested.

\section{DPPH radical-scavenging efficacy of EAFPB}

It was recorded that the percentage inhibition of DPPH radical by EAFPB is concentration-dependent. The $\mathrm{DPPH}$ radical scavenging expressed as the efficient
Table 1 Phytochemical constituents of EAFPB

\begin{tabular}{ll}
\hline Phytochemical & Concentration \\
\hline Tannins & $39.93 \pm 1.03(\mathrm{mg} / 100 \mathrm{~g})$ \\
Phenolics & $20.77 \pm 0.4(\mathrm{mgGAE})$ \\
Terpenoids & $12.7 \pm 0.45(\mathrm{mg} / 100 \mathrm{~g})$ \\
Flavonoids & $10.83 \pm 0.72(\mathrm{mg} / 100 \mathrm{~g})$ \\
Alkaloids & $1.5 \pm 0.06(\mathrm{mg} / 100 \mathrm{~g})$ \\
\hline
\end{tabular}

concentration of sample which is able to scavenge $50 \%$ of DPPH free radicals $\left(\mathrm{EC}_{50}\right)$ was $0.395 \mathrm{mg} / \mathrm{ml}$ (Table 2).

\section{Flavonoids, hydrocinnamic acids and phenolic acids derivatives of ethyl acetate fraction of Parkia biglobosa leaves}

The GC chromatograms of the flavonoids, hydrocinnamic acids derivatives and phenolic acids derivatives are presented in Figs. 1, 2 and 3. Twenty-eight (28) flavonoids consisting mainly of kaempferol $(21.31 \mathrm{mg} /$ $100 \mathrm{~g})$, quercetin $(12.84 \mathrm{mg} / 100 \mathrm{~g})$, luteolin $(6.75 \mathrm{mg} /$ $100 \mathrm{~g})$, myricetin $(5.54 \mathrm{mg} / 100 \mathrm{~g})$, naringenin $(2.58 \mathrm{mg} /$ $100 \mathrm{~g})$, and $(+)$-catechin $(1.02 \mathrm{mg} / 100 \mathrm{~g})$ were detected. Four (4) hydrocinnamic acids derivatives namely Pcoumaric acid $(6.73 \mathrm{mg} / 100 \mathrm{~g})$, chicoric acid $(0.66 \mathrm{mg} /$ $100 \mathrm{~g})$, P-coumarin $(0.113 \mathrm{mg} / 100 \mathrm{~g})$, and scopoletin $(0.002 \mathrm{mg} / 100 \mathrm{~g})$ were detected, while eleven (11) phenolic acids derivatives mainly chlorogenic acid $(48.18 \mathrm{mg} /$ $100 \mathrm{~g})$, protocatechuic acid $(21.58 \mathrm{mg} / 100 \mathrm{~g})$, ferulic acid $(14.12 \mathrm{mg} / 100 \mathrm{~g})$, P-hydroxybenzoic acid $(13.84 \mathrm{mg} /$ $100 \mathrm{~g})$, sinapinic acid $(11.78 \mathrm{mg} / 100 \mathrm{~g})$, caffeic acid $(8.94 \mathrm{mg} / 100 \mathrm{~g})$, and salicylic acid $(7.74 \mathrm{mg} / 100 \mathrm{~g})$ were detected in the plant sample.

\section{Effect of EAFPB on glycated hemoglobin and oxidative status of fructose overloaded rats}

Fructose ingestion elevated glycated hemoglobin (HbA1c) and malondialdehyde (MDA) levels of the HFS control compared to normal control (Table 3). The graded doses of EAFPB reduced the HbA1c and MDA levels in the intervention groups (groups 4 and 5) relative to placebo (HFS control). Treatment with fructose, and reference and herbal drugs however, had no

Table 2 DPPH radical-scavenging capacity of the ethyl acetate fraction of Parkia biglobosa leaves

\begin{tabular}{lc}
\hline Concentration $(\mathbf{m g} / \mathrm{ml})$ & \% Inhibition \\
\hline 0.16 & 14.75 \\
0.32 & 35.33 \\
0.48 & 61.41 \\
0.64 & 73.01 \\
0.80 & 85.78 \\
\hline
\end{tabular}

$\mathrm{EC}_{50}=0.395 \mathrm{mg} / \mathrm{ml}$ 


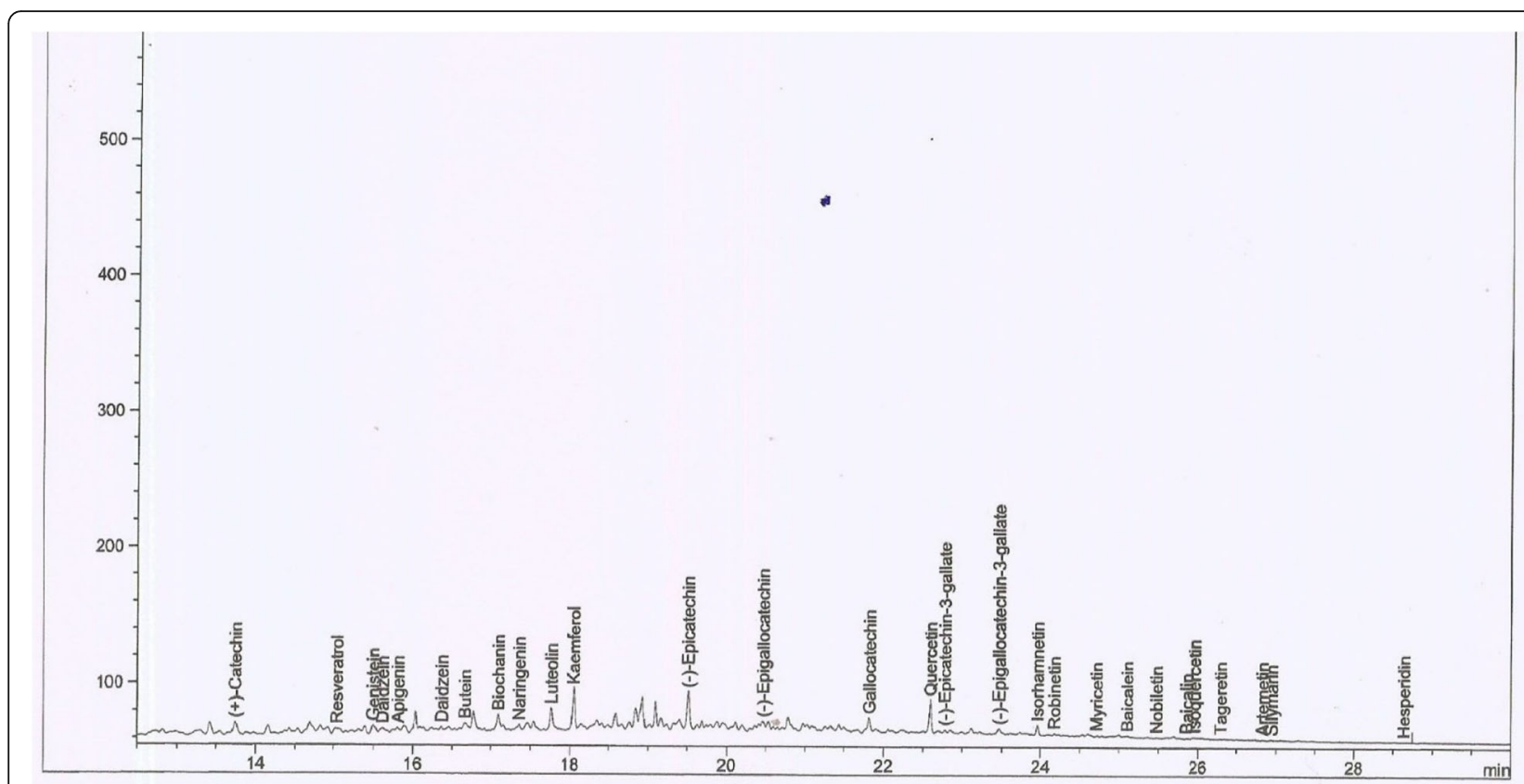

Fig. 1 GC Chromatogram of the "flavonoid composition" of ethyl acetate fraction of $P$. biglobosa leaves

significant effect on serum reduced glutathione concentration in all the groups.

Effect of EAFPB on liver status of fructose overloaded rats Assay of liver enzymes' activities is important in monitoring aberrations in liver function. From the study, high fructose consumption caused elevation in serum activities of alkaline phosphatase (ALP), alanine aminotransferase (ALT), and aspartate aminotransferase (AST) but caused no significant change in bilirubin concentration when compared to control (Table 4). Compared with placebo, treatment with $100 \mathrm{mg} / \mathrm{kg} / \mathrm{d}$ b.w. of EAFPB decreased the serum total bilirubin concentration, and
ALP and AST activities but not ALT activity. However, treatment with $200 \mathrm{mg} / \mathrm{kg} / \mathrm{d}$ b.w. dose of EAFPB decreased serum total bilirubin, ALP and ALT activities but not AST activity when compared to placebo.

\section{Effect of EAFPB on lipid profile of experimental rats}

The untreated rats had higher serum cholesterol, triglyceride, and LDL, but no significant change in serum HDL compared to the normal control (Table 5). Treatment with $100 \mathrm{mg} / \mathrm{kg} / \mathrm{d}$ b.w. of EAFPB caused a reduction in serum cholesterol, triglyceride, and low density lipoproteins concentrations, and an increase in high density lipoprotein concentration of the treated rats

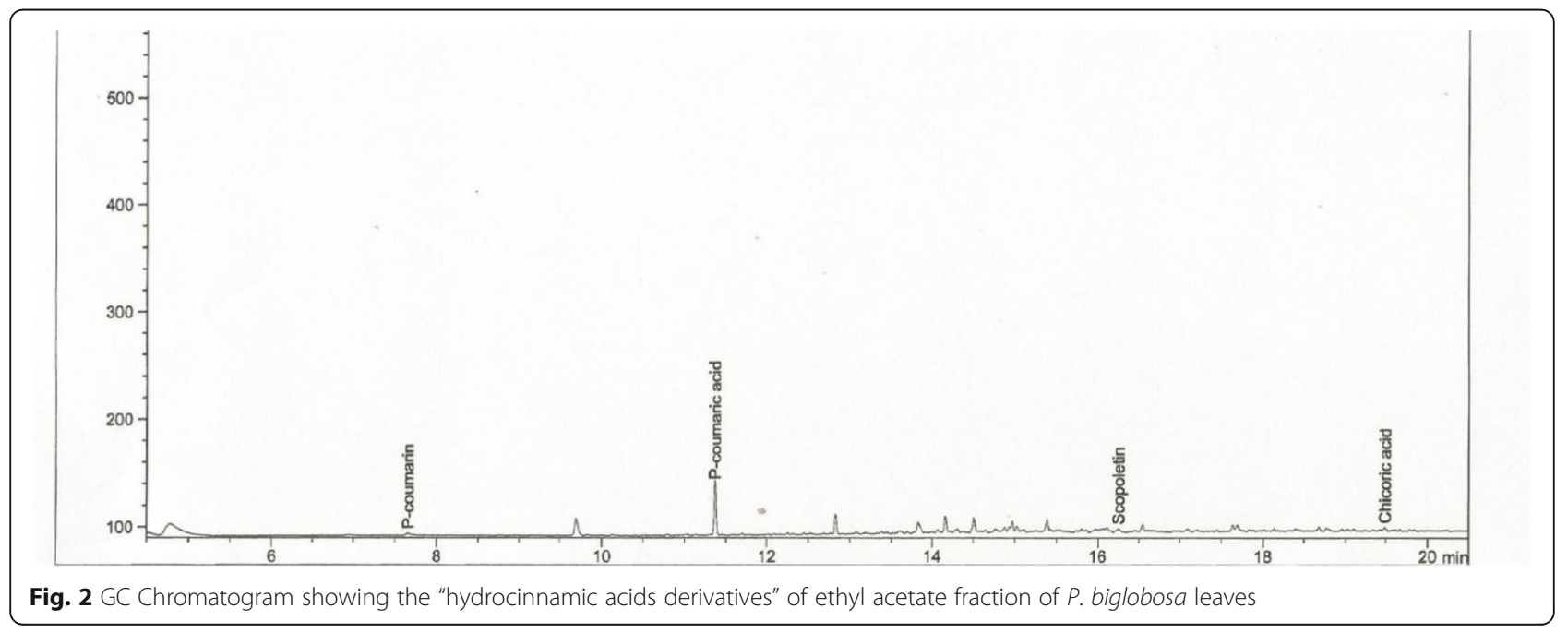




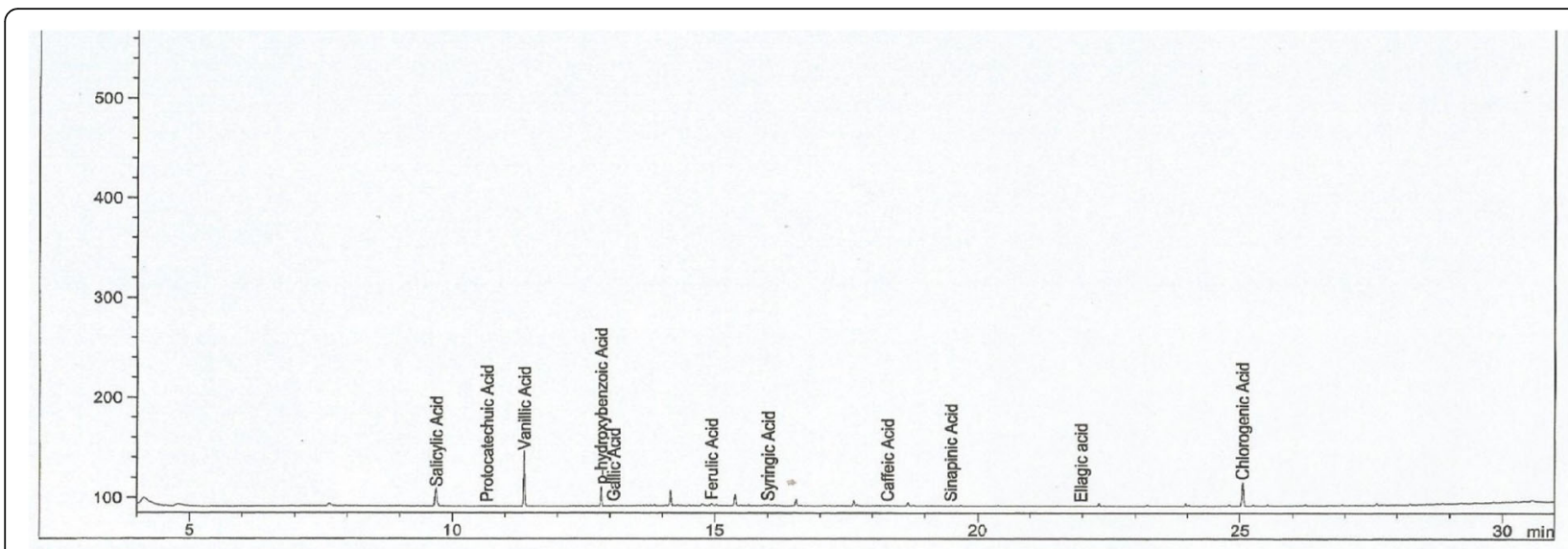

Fig. 3 GC Chromatogram showing the "phenolic acids derivatives" of ethyl acetate fraction of P. biglobosa leaves

compared to the untreated group. On the other hand, the $200 \mathrm{mg} / \mathrm{kg} / \mathrm{d}$ b.w. of EAFPB reduced the serum cholesterol, triglyceride, and LDL concentrations but had no effect on HDL concentration of the treated rats compared to placebo.

\section{Discussion}

The therapeutic effects of many plant products are often associated with their anti-oxidative properties which is attributed to the biological activities of constituent polyphenolic compounds such as flavonoids and phenolic acids. In this present study, the primary phytochemical evaluation of the ethyl acetate fraction of $P$. biglobosa leaves (EAFPB) revealed the presence of phenolics, tannins, flavonoids, terpenoids and alkaloids, with the tannin and phenolic contents substantially higher than the rest. The gas chromatography analysis of the fraction revealed 28 known flavonoids (mainly kaemferol, quercetin, and luteolin), four hydrocinnamic acids derivatives (mainly P-coumaric acid), and 11 phenolic acids derivatives (mainly chlorogenic acid and protocatechuic acid). Polyphenolic compounds are potent disruptors of the damaging effects of free radicals via their antioxidant activities [21, 30], therefore, the presence of these

Table 3 Effect of EAFPB on glycated hemoglobin and some antioxidant parameters of fructose overloaded rats

\begin{tabular}{llll}
\hline Groups & HbA1c & MDA & GSH \\
\hline Normal control & $3.39 \pm 0.58^{\mathrm{b}}$ & $18.13 \pm 1.88^{\mathrm{b}}$ & $5.04 \pm 0.74^{\mathrm{a}}$ \\
HFS control (placebo) & $4.95 \pm 0.21^{\mathrm{a}}$ & $21.31 \pm 0.75^{\mathrm{c}}$ & $4.69 \pm 0.76^{\mathrm{a}}$ \\
Reference group & $3.28 \pm 0.35^{\mathrm{b}}$ & $13.24 \pm 1.40^{\mathrm{a}}$ & $5.46 \pm 1.35^{\mathrm{a}}$ \\
$100 \mathrm{mg} / \mathrm{kg} / \mathrm{d}$ EAFPB & $2.80 \pm 0.34^{\mathrm{b}}$ & $14.56 \pm 0.80^{\mathrm{a}}$ & $5.83 \pm 0.74^{\mathrm{a}}$ \\
$200 \mathrm{mg} / \mathrm{kg} / \mathrm{d}$ EAFPB & $3.20 \pm 0.62^{\mathrm{b}}$ & $19.46 \pm 0.95^{\mathrm{b}}$ & $5.05 \pm 0.78^{\mathrm{a}}$ \\
\hline
\end{tabular}

Data represent mean $\pm \mathrm{SD}(n=5)$; values with dissimilar alphabets as superscripts are significant at $p<0.05$ compounds in the fraction suggests that EAFPB could have antioxidant capacity. In the presence of an antioxidative compound, the violet color of DPPH in ethanol solution is de-colorized to yellow [31]. In this study, a concentration-dependent increase in percentage inhibition of DPPH radicals was observed. This radical scavenging property demonstrated by EAFPB could be linked with some of the detected compounds such as chlorogenic acid, quercetin, kaempferol, and ferulic acid whose antioxidant potentials are known [32]. Furthermore, this result agrees with the finding of Komolafe and Oyelade [33] that attributed the anti-oxidative effect observed in their study to the phenolic and flavonoid contents of the leaf extract, although the authors did not identify the particular compounds suspected.

The link between biological products of glycation and the pathophysiology of many conditions like neurodegenerative disorders, diabetes and its complications, aging and progression of some tumors are known [34]. Relative to normal control, significant elevation in HbA1c levels were observed in placebo rats. HbA1c levels were however lower in fructose-fed rats that received EAFPB than in placebo. High level of circulating fructose is positively correlated to the glycation of both intra- and extracellular proteins including hemoglobin. The rate of non-enzymatic reactivity of fructose with hemoglobin is reported to be 7.5 -fold higher than glucose because fructose metabolism generates intermediates that easily undergo glycation [6, 35]. Our result showed markedly reduced HbA1c levels in the EAFPBtreated rats, which may be attributed to the polyphenolic compounds in EAFPB. Wu et al. [36] reported that chlorogenic and ferulic acids, which are among the polyphelics detected in EAFPB, inhibited glucose mediated protein modification and subsequent cross-linking. Furthermore, luteolin and quercetin which were also present in EAFPB were earlier reported to reduce 
Table 4 Effect of EAFPB on some liver function parameters of fructose overloaded rats

\begin{tabular}{|c|c|c|c|c|}
\hline Groups & ALP (IU/L) & ALT (IU/L) & AST (IU/L) & T. Bilirubin \\
\hline Normal control & $49.60 \pm 7.16^{\mathrm{a}}$ & $14.80 \pm 4.32^{\mathrm{a}}$ & $36.40 \pm 1.82^{\mathrm{a}}$ & $1.85 \pm 0.25^{\mathrm{abc}}$ \\
\hline HFS control (placebo) & $64.20 \pm 14.65^{b}$ & $21.80 \pm 3.90^{\mathrm{b}}$ & $56.20 \pm 4.66^{c}$ & $2.29 \pm 0.14^{c}$ \\
\hline Reference group & $50.80 \pm 4.97^{\mathrm{a}}$ & $14.60 \pm 1.82^{\mathrm{a}}$ & $35.60 \pm 5.55^{\mathrm{a}}$ & $2.02 \pm 0.21^{b c}$ \\
\hline $100 \mathrm{mg} / \mathrm{kg} / \mathrm{d}$ EAFPB & $50.60 \pm 8.44^{\mathrm{a}}$ & $18.00 \pm 2.35^{\mathrm{ab}}$ & $44.80 \pm 5.26^{b}$ & $1.61 \pm 0.50^{\mathrm{ab}}$ \\
\hline 200 mg/kg/d EAFPB & $46.00 \pm 8.28^{\mathrm{a}}$ & $15.20 \pm 4.15^{\mathrm{a}}$ & $50.40 \pm 9.04^{b c}$ & $1.40 \pm 0.72^{\mathrm{a}}$ \\
\hline
\end{tabular}

Data represent mean \pm SD $(n=5)$; values with dissimilar alphabets as superscripts are significant at $p<0.05$

HbA1c levels and different stages of advanced glycation end-product (AGE) production [37]. The anti-glycation activity of polyphenols is postulated to occur through nucleophilic attack on the side chain of AGE structures, thus inhibiting glycoxidation of proteins [38, 39].

Apart from the generation of toxic intermediates such as glyoxal and methylglyoxal, increased fatty acid synthesis and overload to mitochondria increases the generation of reactive species that result in enhanced lipid peroxidation and consequent oxidative stress [6]. The increased serum concentration of malondialdehyde (MDA) in the placebo is an indication of elevated peroxidation of lipids and oxidative stress. However, the significant reduction in MDA concentration in the EAFPB-treated groups indicates good anti-oxidative property of the plant fraction as a result of its rich polyphenolic constituents such as kaempferol and quercetin which have been shown to effectively counter intracellular oxidative stress [40]. The positive effect of $P$. biglobosa extract on toxicant-induced mitochondrial dysfunction and reactive oxygen species (ROS) generation as reported by Komolafe et al. [31] also supports the result of this study. Additionally, the presence of luteolin which has been shown to suppress the expression inflammatory cytokine, boost antioxidant status and decrease lipid peroxidation in diabetic condition [41], might be responsible for the health benefits recorded in this study. Due to their electrondonating capacities, polyphenols are capable of transferring electron(s) to free radicals to stabilize them and prevent their oxidative damage to cellular components and peroxidation of lipids [42]. Meanwhile, the nonsignificant effect of EAFPB on serum reduced glutathione concentration however, indicates that its antioxidant effect that might be independent of the glutathione pathway. In agreement with the present findings, polyphenols-rich extracts have been shown to abrogate experimentally-induced glycation and tissue oxidative damage via antioxidant potentials, metal-complexing properties, protein interaction, methylglyoxal trapping, and inhibition of receptor for AGE (RAGE)/NF-kB pathway activation, as well as boosting of antioxidant defence system [43, 44]. Furthermore, the antiglycation potentials of herbal entities have been documented to be directly correlated with the polyphenolic content $[45,46]$. This observation strongly suggests that bioavailable polyphenolrich plant-based diets have potential application in the prevention and treatment of glycation-mediated conditions such as diabetes, atherosclerosis, and neurodegenerative and end-stage renal diseases [47-49].

Monitoring changes in biochemical profile such as the transaminases is one of the commonest methods of detecting liver dysfunctionality. High calorie diets are implicated in the development of non-alcoholic hepatic abnormalities such as fibrosis, cirrhosis, steatosis, and even hepatocellular carcinoma [50]. The result of this study shows significantly elevated activities of liver function enzymes (ALP, ALT, and AST) after prolonged administration of HFS without treatment (placebo). Elevated serum activities of these enzymes are suggestive of fructose overload-related hepatotoxicity. Earlier studies reported increased inflammation and hepatic endoplasmic reticulum (ER) stress in high fructose supplemented rats, further highlights the toxic effects of fructose overload on hepatic cells [51, 52]. Elevated fructose metabolism increases de novo lipogenesis with consequent hepatic fat accumulation along with ER and mitochondrial stresses, increasing lipotoxicity [50, 53]. When compared with placebo, treatment with EAFPB

Table 5 Effect of EAFPB on lipid profile of high fructose-fed rats

\begin{tabular}{lllll}
\hline Groups & T. CHOL & TRIG & HDL & LDL \\
\hline Normal control & $74.20 \pm 16.74^{\mathrm{a}}$ & $72.20 \pm 7.44^{\mathrm{a}}$ & $66.60 \pm 7.23^{\mathrm{ab}}$ & $50.60 \pm 14.05^{\mathrm{a}}$ \\
HFS control (placebo) & $93.00 \pm 14.14^{\mathrm{b}}$ & $86.80 \pm 9.21^{\mathrm{b}}$ & $52.00 \pm 12.27^{\mathrm{a}}$ & $80.60 \pm 7.16^{\mathrm{b}}$ \\
Reference group & $60.60 \pm 8.85^{\mathrm{a}}$ & $66.20 \pm 9.37^{\mathrm{a}}$ & $65.60 \pm 10.57^{\mathrm{ab}}$ & $45.60 \pm 9.24^{\mathrm{a}}$ \\
$100 \mathrm{mg} / \mathrm{kg} / \mathrm{d}$ EAFPB & $65.80 \pm 6.61^{\mathrm{a}}$ & $73.00 \pm 7.25^{\mathrm{a}}$ & $69.60 \pm 9.10^{\mathrm{b}}$ & $47.60 \pm 9.61^{\mathrm{a}}$ \\
$200 \mathrm{mg} / \mathrm{kg} / \mathrm{d}$ EAFPB & $60.00 \pm 12.67^{\mathrm{a}}$ & $60.40 \pm 9.79^{\mathrm{a}}$ & $62.80 \pm 14.34^{\mathrm{ab}}$ & $46.00 \pm 6.52^{\mathrm{a}}$ \\
\hline
\end{tabular}

Data represent mean $\pm \mathrm{SD}(n=5)$; values with dissimilar alphabets as superscripts are significant at $p<0.05$ 
significantly attenuated the fructose-induced upregulation of serum activities of these enzymes, indicating a hepatoprotective property. This observation is suspected to result from the presence and bioactivity of the polyphenols in EAFPB. This class of compounds are associated with potent antioxidant activities albeit via different mechanisms. For example, $p$-coumaric acid reduces hepatic fat accumulation by increasing AMPK expression [54], while quercetin improves lipid metabolism via activation of Akt signalling [55]. In addition, kaempferol has been shown to prevent lipid accumulation while enhancing antioxidant defense in hepatocytes [56]. Although no significant change in serum bilirubin concentration in the HFS group relative to normal control, the result suggests that prolonged fructose overload could result in hyperbilirubinemia. Similarly, only the highest dose of EAFPB $(200 \mathrm{mg} / \mathrm{kg})$ caused a significant reduction in serum bilirubin levels compared to placebo, suggesting improved bilirubin metabolism and excretion by the liver. The overall improvement of hepatic markers agrees with the reports of Gasparotto et al. [57] that polyphenols from peach-derived products attenuated $\mathrm{CCl}_{4}$-generated oxidative stress and liver damage by down-regulating AGE receptor expression. Ibrahim et al. [11] also reported improvements in hepatic markers of diabetic rats treated with $P$. biglobosa butanol fraction, which further supports the result of this study.

Fructose overload causes aberrations in lipid metabolism via glycation- and oxidative stress-dependent mechanisms. Fructose upregulates the expression of transcriptional regulators of hepatic lipogenesis, the sterol regulatory element-binding protein-1c (SREBP-1c) and carbohydrate response element binding protein $(C h R E B P)$, consequently up-regulating their downstream targets, acetyl Coenzyme A carboxylase $(A C C)$ and fatty acid synthase $(F A S N)$, the key enzymes of fatty acids biosynthetic pathway [5,58]. High fructose consumption thus causes dyslipidemia by increasing hepatic lipogenesis and triglyceride synthesis while counteracting the $\beta$-oxidation of fatty acids [6]. Significant increase in serum levels of lipid markers (cholesterol, triglyceride, and low-density lipoproteins) was observed in this study when placebo is compared with normal control. This further confirms the detrimental effect of fructose overload. Treatment with the plant fraction caused significant improvement in lipid profile of the experimental rats. Earlier studies by Ibrahim et al. [11] also reported improvements in lipid profile of type-2 diabetic rats treated with butanol fraction of this plant, linking it to the insulinotropic effect of the plant in diabetic rats. P-coumaric and ferulic acids are reported to decrease the expression of adipocyte differentiation markers, thus reducing unwanted lipid accumulation [59].

\section{Conclusions}

The result of this study showed that ethyl acetate fraction of Parkia biglobosa leaves contains a good number of health-promoting polyphenolic compounds which are inferred to be responsible for the observed beneficial effects on the biochemical status of fructose overloaded rats. To the best of the knowledge of the researchers, this is the first-time efforts were made to investigate the phytochemical constituents of Parkia biglobosa leaves. The exact mechanism of action of Parkia polyphenols in reversing sugar-induced biochemical aberrations is, however, still a subject of further research.

\section{Abbreviations}

EAFPB: Ethyl acetate fraction of Parkia biglobosa leaves; HFS: High fructose solution; HbA1c: Glycated hemoglobin; AST: Aspartate aminotransferase; ALT: Alanine aminotransferase; ALP: Alkaline phosphatase; MDA: Malondialdehyde; DPPH: 2,2-diphenyl-1-picrylhydrazyl; GC-FID: Gas chromatography coupled flame ionization detector; LDL: Low density lipoprotein; HDL: High density lipoprotein; TRIG: Triglyceride; EC50: Efficient concentration of sample that can inhibit 50\% of the reaction; AGE: Advanced glycation end-product; RAGE: Advanced glycation end-product receptor; ROS: Reactive oxygen species; SREBP-1c: Sterol regulatory element-binding protein-1c; ChREBP: Carbohydrate response element binding protein; ACC : Acetyl Coenzyme A carboxylase; FASN: Fatty acid synthase

\section{Acknowledgements}

not applicable.

Authors' contributions

CCC and ABC conceived and designed the work, CCC, ARO, OIU and NCC collected and analyzed the data, CCC and OIU drafted the manuscript. All the authors read and approved the final manuscript.

Funding

not applicable.

Availability of data and materials

The dataset supporting the conclusions of this article is included within the article.

\section{Declarations}

Ethics approval and consent to participate

The study protocols were approved by the Faculty of Biological Science Committee on Research Ethics, University of Nigeria, Nsuka (UNN/FBS/EC/ 1056).Other national and international guidelines for the care and use of animals for research were strictly followed in this study.

\section{Consent for publication}

not applicable.

\section{Competing interests}

The authors declare that they have no competing interests.

\section{Author details}

'Department of Biochemistry, Medical Biochemistry, Toxicology and Drug Discovery Unit, University of Nigeria, Enugu State, Nsukka, Nigeria. ${ }^{2}$ Institute for Drug-Herbal Medicine-Research and Development, University of Nigeria, Nsukka, Enugu State, Nigeria. 
Received: 30 December 2020 Accepted: 12 April 2021

\section{Published online: 30 April 2021}

\section{References}

1. Basciano H, Federico L, Adeli K. Fructose, insulin resistance, and metabolic dyslipidemia. Nutr Metab. 2005;2:5.

2. Stephenson K, Kennedy L, Hargrove L, et al. Updates on dietary models of non-alcoholic fatty liver disease: current studies and insights. Gene Expr. 2018;18(1):5-17.

3. Hannou SA, Haslam DE, McKeown NM, Herman MA. Fructose metabolism and metabolic disease. J Clin Invest. 2018;128(2):545-55.

4. Selvin E, Steffes MW, Zhu H, et al. Glycated hemoglobin, diabetes, and cardiovascular risk in nondiabetic adults. New England J Med. 2010;362(9): 800-11.

5. Softic S, Gupta MK, Wang G, et al. Divergent effects of glucose and fructose on hepatic lipogenesis and insulin signaling. The J Clin Invest. 2017;127(11): 4059-74.

6. Aragno M, Mastrocola R. Dietary sugars and endogenous formation of advanced glycation end products: emerging mechanisms of disease. Nutrients. 2017;9:385.

7. Joshua PE, Okagu IU, Eze CS, et al. Effects of commercial herbal preparation (HP) used in Nigeria on lipid profile of acetaminophen-intoxicated rats. PharmacologyOnline. 2018;3:216-22.

8. Enechi OC, Okagu IU, Ndefo JC, et al. Methanol extract of Peltophorum pterocarpum stem bark has antimalarial activity and normalizes biochemical changes induced by Plasmodium berghei infection. Adv Life Sci Tech. 2019; 73:43-52.

9. Chan-Sik K, Sok P, Junghyun K. The role of glycation in the pathogenesis of aging and its prevention through herbal products and physical exercise. J Exercise Nutr Biochem. 2017;21(3):55-61.

10. Odetola AA, Akinloye O, Egunjobi C, et al. Possible antidiabetic and antihyperlipidemic effect of fermented Parkia biglobosa (Jacq) extract in alloxan-induced diabetic rats. Clin Exp Pharmacol Physiol. 2006;33:808-12.

11. Ibrahim MA, Habila JD, Koorbanally NA, Islam S. Butanol fraction of Parkia biglobosa (Jacq.) G. Don leaves enhance $\beta$-cell functions, stimulates insulin secretion and ameliorates other type 2 diabetes-associated complications in rats. J Ethnopharmacol. 2016; 183: 103-111.

12. Ibrahim MA, Koorbanally NA, Islam MS. In vitro anti-oxidative activities of the various parts of Parkia biglobosa and GC-MS analysis of extracts with high activity. Afr J Trad Complement Altern Med 2013; 10(5): 283-291.

13. Nwankwo PO. Extraction, fractionation and assessment of antioxidant activities of active components of Aframomum sceptrum seeds. Afr J Biochem Res. 2015;9(10):117-23.

14. Harborne JB. Phytochemical methods. London: Chapman and Hall Limited 1973.

15. Trease GE, Evans WC. Phenols and phenolic glycosides in Textbooks of pharmacology. 12th ed. London: Balliese, Tindall and Co. Publishers; 1983.

16. Ortan A, Popescu ML, Gaita AL, et al. Contributions to the pharmacognostical study on Anethum graveolens, Dill (Apiaceae). Roman Biotech Letters. 2009;14:4342-8.

17. Millogo-Kone $\mathrm{H}$, Lompo M, Kini F, et al. Evaluation of flavonoids and total phenolic contents of stem bark and leaves of Parkia biglobosa (Jaca.) Benth. (Mimosaceae)-free radical scavenging and antimicrobial activities. Res J Med Sci. 2009;3:70-4.

18. Kelley WT, Coffey DL, Mueller TC. Liquid chromatographic determination of phenolic acids in soil. J AOAC Int. 1994;77:805-9

19. Provan GJ, Scobbie L, Chesson A. Determination of phenolic acids in plant cell walls by microwave digestion. J Sci Food Agric. 1994;64:63-5.

20. Whitehead D, Dibb CH, Hartley RD. Bound phenolic compounds in water extracts of soils, plant roots, and leaf litter. Soil Biol Biochem. 1983;15:133-6.

21. Lee SY, Mediani A, Ismail IS, et al. Antioxidants and a-glucosidase inhibitors from Neptunia oleracea fractions using ${ }^{1} \mathrm{H}$ NMR-based metabolomics approach and UHPLC-MS/MS analysis. BMC Complement Altern Med. 2019; $19 \cdot 7$

22. Jendrassik J, Grof P. In vitro determination of total and direct bilirubin in serum or plasma. Biochemistry. 1938;6:269-75.

23. Reitman S, Frankel S. A colorimetric method for the determination of serum glutamic oxaloacetic and glutamic pyruvic transaminases. Am J Clin Pathol. 1957;28:56-63.

24. Englehardt A. Measurement of alkaline phosphatase. Aerztl Labor. 1970;16: 42-3.
25. Wallin B, Rosengren B, Shertzer HG, Camejo G. Lipoprotein oxidation and measuring of thiobarbituric acid reacting substances (TBARS) formation in a single microtiter plate: Its use for evaluation of antioxidants. Anal Biochem. 1993:208:10-5.

26. Habig WH, Pabst MJ, Jakoby WB. Glutathione-S-transferases. The first enzymatic step in mercapturic acid formation. J Biol Chem. 1974;249(22):7130-9.

27. Allain CC, Poon LS, Chan CSG, et al. Enzymatic determination of total serum cholesterol. Clin Chem. 1974:20:470-5.

28. Albers JJ, Warmick GR, Cheng MC. Determination of high-density lipoprotein (HDL)-cholesterol. Lipids. 1978;13:926-32.

29. Friedewald WT, Levy RI, Fredrickson DS. Estimation of the concentration of low-density lipoprotein cholesterol in plasma, without use of the preparative ultracentrifuge. Clin Chem. 1972;18(6):499-502.

30. Ross JA, Kasum CM. Dietary flavonoids: Bioavailability, metabolic effects, and safety. Annual Rev Nutr. 2002;22:19-34.

31. Komolafe K, Akinmoladun AC, Komolafe TR, et al. African locust bean (Parkia biglobosa, Jacq Benth) leaf extract affects mitochondrial redox chemistry and inhibits angiotensin converting enzyme in vitro. Clin Phytosci. 2017;3:19.

32. Liang N, Kitts DD. Role of chlorogenic acids in controlling oxidative and inflammatory stress conditions. Nutrients. 2016;8:16.

33. Komolafe K, Oyelade WA. Phytochemical screening and in vitro antioxidant activity of Parkia biglobosa extract. J Biol Agric Healthcare. 2015;5(9):91-5.

34. Fournet $\mathrm{M}$, Bonté $\mathrm{F}$, Desmoulière $\mathrm{A}$. Glycation damage: a possible hub for major pathophysiological disorders and aging. Aging Disease. 2018;9(5): 880-900.

35. Bunn HF, Higgins PJ. Reaction of monosaccharides with proteins: possible evolutionary significance. Science. 1981;213:222-4.

36. Wu CH, Yeh CT, Shih PH, Yen GC. Dietary phenolic acids attenuate multiple stages of protein glycation and high-glucose-stimulated pro-inflammatory IL-1beta activation by interfering with chromatin remodeling and transcription in monocytes. Mol Nutr Food Res. 2010;54(2):127-40

37. Wu CH, Yen GC. Inhibitory effect of naturally occurring flavonoids on the formation of advanced glycation end-products. J Agric Food Chem. 2005;53: 3167-73.

38. Xie $Y$, Chen X. Structures required of polyphenols for inhibiting advanced glycation end products formation. Cur Drug Metab. 2013;14:414-31.

39. Sadowska-Bartosz I, Bartosz G. Prevention of protein glycation by natural compounds. Molecules. 2015;20:3309-34.

40. Hofer S, Geisler S, Lisandrelli R, et al. Pharmacological targets of kaempferol within inflammatory pathways - a hint towards the central role of tryptophan metabolism. Antioxidants (Basel). 2020;9(2):180.

41. Lu H, Chen $Y$, Sun XB, et al. Effects of luteolin on retinal oxidative stress and inflammation in diabetes. RSC Advances. 2015:5(7):4898-904.

42. Yeh WJ, Hsia SM, Lee WH, Wu CH. Polyphenols with antiglycation activity and mechanisms of action: A review of recent findings. J Food Drug Anal. 2017;25:84-92.

43. Dom NSM, Yahaya N, Adam Z, et al. Antiglycation and antioxidant properties of Ficus deltoidea varieties. Evidence-Based Complement Altern Med. 2020: 6374632

44. Jovanovic' JA, Mihailovic' M, Uskokovic' AS, et al. Evaluation of the antioxidant and antiglycation effects of Lactarius deterrimus and Castanea sativa Extracts on hepatorenal injury in streptozotocin-induced diabetic rats. Front Pharmacol. 2017:8:793.

45. Ramkissoon JS, Mahomoodally MF, Ahmed N, Subratty AH. Antioxidant and anti-glycation activities correlates with phenolic composition of tropical medicinal herbs. Asian Pac J Trop Med. 2013: 561-569.

46. Elosta A, Slevin M, Rahman K, Ahmed N. Aged garlic has more potent antiglycation and antioxidant properties compared to fresh garlic extract in vitro. Sci Rep. 2017;7:39613.

47. Ahmed N. Advanced glycation endproducts - role in pathology of diabetic complications. Diabetes Res Clin Pract. 2005;67:3-21.

48. Quero J, Marmol I, Cerrada E, Rodríguez-Yoldi MJ. Insight into the potential application of polyphenol-rich dietary intervention in degenerative disease management. Food Funct. 2020;11(4):2805-25.

49. Spagnuolo L, Della Posta S, Fanali C, et al. Antioxidant and antiglycation effects of polyphenol compounds extracted from hazelnut skin on advanced glycation end-products (ages) formation. Antioxidants. 2021;10:424.

50. Nassir F, Rector RS, Hammoud GM, Ibdah JA. Pathogenesis and prevention of hepatic steatosis. Gastroenterol Hepatol. 2015;11(3):167-75.

51. Balakumar M, Raji L, Prabhu D, et al. High-fructose diet is as detrimental as high-fat diet in the induction of insulin resistance and diabetes mediated 
by hepatic/pancreatic endoplasmic reticulum (ER) stress. Mol Cell Biochem. 2016:423(1-2):93-104.

52. Bora K, Borah M, Chutia H, et al. Presence of concurrent derangements of liver function tests in type 2 diabetes and their relationship with glycemic status: A retrospective observational study from Meghalaya. J Lab Physic. 2016;8(1):30-5

53. Neuschwander-Tetri BA. Hepatic lipotoxicity and the pathogenesis of nonalcoholic steatohepatitis: the central role of non-triglyceride fatty acid metabolites. Hepatology. 2010;52(2):774-88.

54. Pei K, Ou J, Huang J, Ou S. p-Coumaric acid and its conjugates: dietary sources, pharmacokinetic properties and biological activities. J Sci Food Agric. 2016;96:2952-62

55. Peng J, Li Q, Li K, et al. Quercetin improves glucose and lipid metabolism of diabetic rats: involvement of Akt signaling and SIRT1. J Diabetes Res. 2017; 2017. 3417306.

56. Wang M, Sun J, Jiang Z, et al. Hepatoprotective effect of kaempferol against alcoholic liver injury in mice. Am J Chinese Med. 2015:43:241-54.

57. Gasparotto J, Somensi N, Bortolin RC, et al. Effects of different products of peach (Prunus persica L. Batsch) from a variety developed in Southern Brazil on oxidative stress and inflammatory parameters in vitro and ex vivo. J Clin Biochem Nutr. 2014; 55(2): 110-119.

58. Mastrocola R, Nigro D, Chiazza F, et al. Fructose-derived advanced glycation endproducts drive lipogenesis and skeletal muscle reprogramming via SREBP-1c dysregulation in mice. Free Radic Biol Med. 2016;91:224-35.

59. Seo CR, Yi BR, Oh S, et al. Aqueous extracts of hulled barley containing coumaric acid and ferulic acid inhibit adipogenesis in vitro and obesity in vivo. J Funct Foods 2015; 12: 208-218.

\section{Publisher's Note}

Springer Nature remains neutral with regard to jurisdictional claims in published maps and institutional affiliations.

\section{Submit your manuscript to a SpringerOpen ${ }^{\circ}$ journal and benefit from:}

- Convenient online submission

- Rigorous peer review

- Open access: articles freely available online

- High visibility within the field

- Retaining the copyright to your article

Submit your next manuscript at $\boldsymbol{\nabla}$ springeropen.com 